\title{
Determination of antibacterial activity in rhizome of plant Aechmea magdalenae (andre) andre ex baker
}

\author{
Gaganpreet Kaur Monga, Anima Ghosal, Daniela Shebitz, Dil Ramanathan
}

New Jersey Center for Science, Technology \& Mathematics - Kean University, Union, NJ

Received: 20.06 .2017

Accepted: $12-10-2017$

Published: 18.12 .2017

*Address for Correspondence:

Dr. Dil Ramanathan, New Jersey Center for Science, Technology \& Mathematics Kean University, Union, NJ.

E-mail: ramanatd@kean.edu

\begin{abstract}
The rising resistance of microbes toward the present-day antibiotics has led the researchers to increasingly investigate medicinal plant-based antibiotics. The plant Aechmea magdalenae (Andre) Andre ex Baker (Bromeliaceae) is a terrestrial bromeliad native to Central America and Northwestern South America. Throughout much of its range, the juice from the leaves of $A$. magdalenae has been used by locals as caustic for wounds. In the lowland wet forests of Costa Rica, however, the local herbal healers do not rely on this species. In this study, antibacterial and biochemical analyses were conducted on $A$. magdalenae to document its potential use as a medicinal plant for both the local people in Costa Rica and to the scientific community. Gas chromatography-mass spectrometry profiling studies also revealed, acetic acid to be one of the important chemical compound present in high probability in $A$. magdalenae. The antibacterial activity was confirmed by performing agar disc diffusion assay using various concentrations of acetic acid against bacteria Escherichia coli. Acetic acid clearly demonstrated its antibacterial effect against $E$. coli. The antibacterial activity of the methanolic extracts of $A$. magdalenae was tested against Gram-negative (E. coll) and Gram-positive bacteria (Staphylococcus aureus). The methods used to determine the antibacterial activity of the plant extracts were agar well diffusion assay and 96-well plate assay. In both the assays, gentamicin was used as a positive control and $20 \%$ dimethyl sulfoxide was used as a negative control. In 96 well plate assay, resazurin was used as an indicator to evaluate qualitatively whether the bacteria there was the growth of the bacteria or no growth. All the tests were performed in triplicates. The zones of inhibition recorded were higher for $S$. aureus $(10.5 \mathrm{~mm})$ as compared to $E$. coli $(9.5 \mathrm{~mm})$. The minimum inhibitory concentration for $E$. coli was higher as compared to $S$. aureus.
\end{abstract}

KEY WORDS: 96 well-plate assay, Aechmea magdalenae (Andre) Andre ex Baker, antibacterial activity, Escherichia coli, minimum inhibitory concentration

\section{INTRODUCTION}

Recently, due to the evolution of disease-causing agents and the failure of the available antimicrobials, researchers have been focusing more on investigating natural products as alternatives to synthetic medicines. These natural products could be used to supply new bioactive molecules (Silver and Bostian, 1993; Recio and Rois, 1989). An ethnobotanical approach to drug discovery can involve focusing pharmacological research on plants used traditionally by local or indigenous people to treat ailments (Balick and Cox, 1997). Such research has often revealed that many traditional medicinal plants have strong antimicrobial effects and are important sources of many such bioactive chemical compounds (Webster et al., 2008). Many herbaceous plants belonging to the family Bromeliaceae have antibacterial and antioxidant properties (Santana et al., 2012). The Bromeliaceae family has nearly 3172 species and 58 genera which are grouped into eight subfamilies (Luther, 2008; Givnish et al., 2011). The phytochemical investigation of the family Bromeliaceae has resulted in the isolation of mainly flavonoids and triterpenoids (Manetti et al., 2009). These studies demonstrate a correlation of the phytochemistry with the biological properties of the plants from the family Bromeliaceae.

Aechmea magdalenae (Andre) Andre ex Baker or Bromelia magdalenae is a terrestrial bromeliad mainly distributed in Central America and Northwestern South America. In Central America, it is commonly known as Pingwing, "Pita 
plant,"or "Ixtle"(Ticktin, 2002). A. magdalenae is a perennial herb, with long spiny leaves that grow up to $3.5 \mathrm{~m}$ in length. The plants are mainly found in the dense wet understory of lowland neotropical rain forests. Fruits of $A$. magdalenae are fleshy, edible, and yellowish orange in color (Ticktin, 2002). A. magdalenae shifts between clonal reproduction producing more rhizomes (the underground stem) and ramets or just extending the rosettes. This depends on seasonality such as the duration of dry and wet seasons which have variable intensity of sunlight. During dry season and early wet season, intense sunlight leads to the production of more rhizomes and ramets(Villegas, 2001). The leaves of $A$. magdalenae are used to extract a very durable white fiber that is resistant to salt water. The leaves are retted in water for a long time to extract the fiber, which is then used to weave fine baskets, fishing nets, bags, ropes, strings for musical instruments, mats, etc. The thorns of the leaves are utilized as needles and pins. While A. magdalenae is not recognized widely as a medicinal plant, the indigenous people of Mexico have reportedly used the juice of leaves as caustic for wounds (Ticktin, 2002). The application of A. magdalenae, therefore, would treat and manage wound topically. There is no indication that this plant was ingested as a medicine, although the fruit [Figure 1] reportedly tastes like pineapple (Hazlet, 1986; Lincoln, 2004).

Several species of the genus Bromelia have been studied for the presence of their chemical components responsible for the pharmacological activity. Bromelia pinguin, another terrestrial bromeliad found in the lowland forests of Costa Rica, has been found to have antibacterial and antifungal properties within its fruits and leaves (Camacho-Hernández et al., 2002; Raffauf et al., 1981; Pío-León et al., 2009). The most common reason behind the antimicrobial potential of these plants pertains to the presence of chemical compounds such as diterpenes and flavonoids (Camacho-Hernández

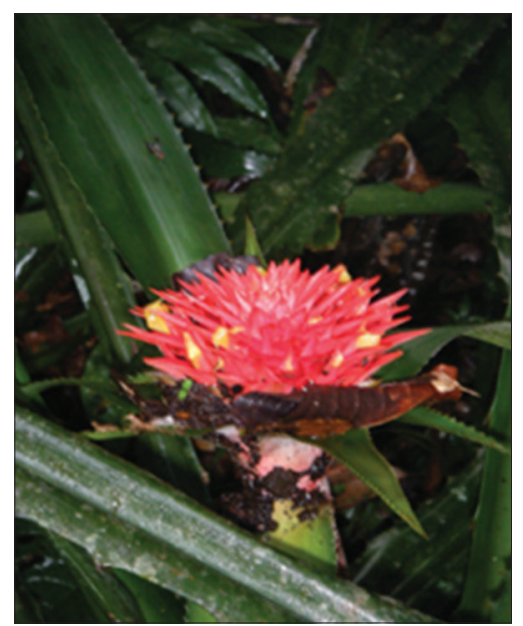

Figure 1: The flower of plant Aechmea magdalenae with leaves et al., 2002). A. magdalenae was analyzed for its chemical composition in our laboratory using gas chromatographymass spectrometry (GC-MS). A preliminary GC-MS profiling of the rhizome of $A$. magdalenae confirmed the presence of antimicrobial compounds such as acetic acid in high probability (90.9\%). Since the leaves of A. magdalenae showed low probability (27.7\%) of acetic acid in GC-MS profiling, we chose the rhizome as our starting material. In addition, the other compounds found in the leaf extracts have known to display some spasmodic and cytotoxic activity (Pío-León et al., 2009; Joung et al., 2008). However, the evidence of any biological activity of rhizome extracts of the entire family Bromeliaceae and the plant $A$. magdalenae (Andre) Andre ex Baker has not yet been documented.

While published research mentions A. magdalenae's use as wound caustic (Ticktin, 2002), to the best of our knowledge, there has not been a thorough investigation pertaining to the biochemistry and antibacterial activity of this species. Despite its use in other parts of its range and its abundance in the understory of lowland wet forests, A. magdalenae is absent from medicinal plant guides of Costa Rica (Shebitz and Eaton, 2013). Similarly, in ethnobotanical interviews conducted with eight healers of the Maquenque National Wildlife Refuge (MNWLR) of Costa Rica from 2010 to 2013, A. magdalenae in particular was not recognized for its medicinal uses (Payrol and Martinez, 2000). However, most of these healers expressed a desire to learn about the medicinal properties of plants in their forests that they may not be using yet. Throughout the lowland wet forests of the MNWLR, A. magdalenae forms monotypic stands and appears to prohibit the growth of associated vegetation, while also influencing the distribution of birds, insects, and another biota. Although it is not ethnobotanically relied on locally for its chemical properties, it is possible that the plants' ecological role is influenced by its chemical composition as well as its extensive underground and aboveground biomass.

In this study, antibacterial and biochemical analyses were conducted on A. magdalenae to document its potential use as a medicinal plant for both the local people in Costa Rica and to the scientific community. This research is designed to initiate a more extensive investigation as to whether the rhizome of $A$. magdalenae has potential to be used as a medicine, either locally by the healers, or perhaps in western pharmaceuticals. The main purpose of this particular study was to determine the antibacterial activity of the methanolic extracts of the A. magdalenae rhizome against Gram-negative and Gram-positive bacteria so that this plant could be used as a potential antibiotic in future. 


\section{MATERIALS AND METHODS}

\section{Plant Collection and Extraction}

The A. magdalenae rhizomes [Figure 2] were collected by Dr. Daniela Shebitz (Kean University) and a local healer from the lowland wet forests of the MNWLR of Costa Rica in the summers of 2015 and 2016. The materials were harvested from young rosettes in areas where the plant naturally grows in monoculture. The rhizomes were first chopped off the plant with a machete and washed with water. The rhizome was then chopped into small pieces to facilitate drying. The pieces were laid on cement initially for $48 \mathrm{~h}$, to expose them to sunlight and then oven dried at $250^{\circ} \mathrm{C}$ until they were thoroughly dried. The pieces were ground using a coffee grinder and then rubbed into a finer powder through a soil sieve.

Plant extracts were prepared by adding $6 \mathrm{~g}$ of the powdered rhizome in $60 \mathrm{ml}$ of the high-performance liquid chromatography grade $(99.9 \%)$ methanol. The sample was kept covered to protect from direct light and agitated on an orbital shaker $(150 \mathrm{rpm})$ for $72 \mathrm{~h}$ at room temperature. The solvent was replenished every $24 \mathrm{~h}$, and the recovered methanol was pooled, filtered using Whatman Filter paper number 1 . The filtrate was dried under vacuum, using rotary evaporator at room temperature (Buchi, R-114). The dried plant extract was weighed and reconstituted in 20\% dimethyl sulfoxide (DMSO). The reconstituted plant extract was refrigerated until further use.

\section{Methods}

\section{Phytochemical screening}

GC-MS is an analytical method that combines GC technique with MS. It is used to isolate the different compound from the mixture test sample. The GC consists of a capillary column which is packed with

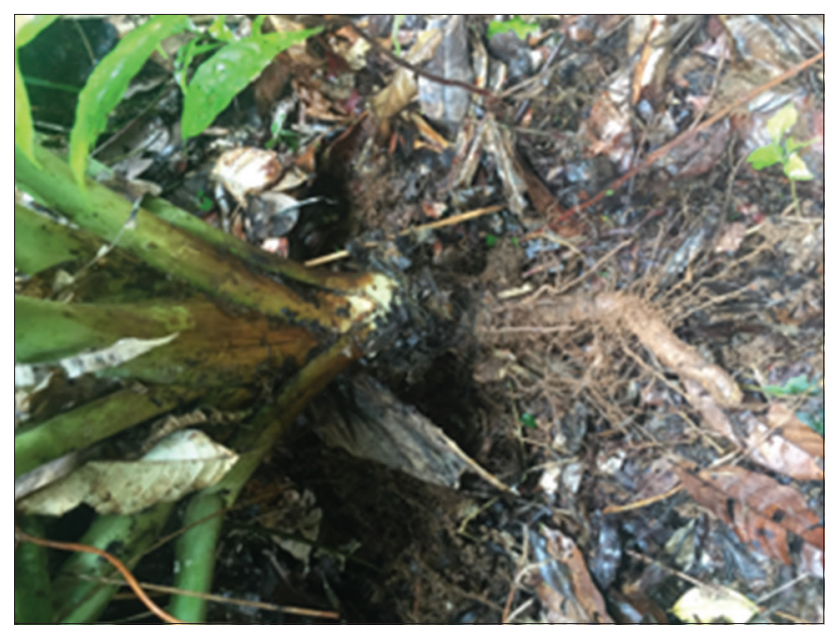

Figure 2: The leaves and the underground rhizome of the plant Aechmea magdalenae stationary and mobile phases. Depending on the relative affinity of the sample components toward the two phases, the compounds get separated and eluted from the column at different retention times. The MS captures and ionizes the separated components, which gets detected using mass to charge ratio. The GC-MS instrument used to profile $A$. magdalenae was by Perkin Elmer. GC-MS analysis performed on powdered rhizome of $A$. magdalenae in our lab demonstrated high probability (90.9\%) of acetic acid which could be responsible for its antibacterial properties.

\section{Antibacterial Activity}

The antibacterial activity of $A$. magdalenae extract was assessed by determining minimum inhibitory concentration (MIC) using agar well diffusion assay and 96 well-plate assays. The Gram-negative bacteria used for this study was E. coli (ATCC 25922), and the Gram-positive bacteria was Staphylococcus aureus (ATCC 25923). Initial bacterial cultures were prepared from the stock culture by adding a sterile loop full of bacteria in $10 \mathrm{ml}$ of sterile LB- broth (10 g peptone, 5 g yeast extract, and $10 \mathrm{~g}$ sodium chloride) and placed the culture vial in the incubator at $37^{\circ} \mathrm{C}$ for $24 \mathrm{~h}$. From this 24 -h bacterial culture, a fresh culture was prepared every time by taking $40 \mu \mathrm{L}$ of inoculum and added into $10 \mathrm{ml}$ of LB-Broth followed by incubation for $24 \mathrm{~h}$ at $37^{\circ} \mathrm{C}$. Then, the bacteria were diluted down to $1 \times 10^{8}$ colony-forming unit $/ \mathrm{ml}$ of 0.5 McFarland standard.

\section{Agar Disc Diffusion Assay}

Agar disc diffusion assay or Kirby-Bauer assay (Bauer et al. , 1966) is a technique to test the sensitivity of existing antibiotics or potential antibiotics. Antibacterial activity of acetic acid was tested using agar disc diffusion assay. Various concentrations of acetic acid ranging between $1 \%$ and $5 \%$ were prepared in sterile water. Several round disks of filter paper were prepared (6 $\mathrm{mm}$ each). Three discs were impregnated separately with $1 \%, 2 \%$, and $5 \%$ acetic acid and the fourth one was loaded with gentamicin (positive control) and fifth one with 20\% DMSO as a negative control. The discs were allowed to sit for $24 \mathrm{~h}$ under the hood to get the acetic acid absorbed properly. The sterile nutrient agar plates were swabbed uniformly by the appropriately diluted ( $0.5 \mathrm{McF}$ arland standard) bacteria. The prepared discs were placed equidistantly on the bacteria-coated agar plate, and the plates were placed upside down in the incubator at $37^{\circ} \mathrm{C}$ for $24 \mathrm{~h}$. The clear areas around the discs were called the zones of inhibition. The zones of inhibition were recorded (in $\mathrm{mm}$ ) after $24 \mathrm{~h}$ of incubation. 


\section{Agar Well Diffusion Assay}

The antibacterial activity was determined using agar well diffusion assay explained by Taye et al. (2011). Several Petri plates were prepared under laminar hood using sterile nutrient agar media and stored in the refrigerator until use. The Petri plates were labeled separately for E. coli and S. aureus followed by uniform spreading of bacteria over nutrient agar Petri plates, using sterile cotton swabs. In each plate, three wells were drilled (6 mm each) using a sterile cork borer. The plant extract was added in one well followed by $20 \%$ DMSO as a negative control in the second well and gentamicin or chlorhexidine as a positive control in the third well. The zone of inhibitions for E. coli and S. aureus was measured (in $\mathrm{mm}$ ), and the MIC were measured as the lowest concentration that showed clear zones of inhibition. The MIC's were determined by adding equal volumes of the plant extract from higher concentration to lower concentration.

\section{Comparative Study of Indicator Resazurin and INT}

Resazurin is a blue colored redox dye commonly used as an indicator of chemical cytotoxicity and cell viability in cultured extracts in agar diffusion assays and 96-well plate assays both in bacteria and mammalian cells. The assays are based on the ability of the viable, metabolically active cells to irreversibly reduce resazurin (blue) to resorufin (pink). Resazurin is reduced in the mitochondria where $\mathrm{NADPH}$ or NADH acts as a reductant to resorufin in the presence of enzyme NADPH dehydrogenase or NADH dehydrogenase [Figure 3] (Rampersad, 2012).

INT dye is 2-(4-iodophenyl)3-(4-nitrophenyl)-5-phenyl$2 \mathrm{H}$ tetrazolium salt, mainly this tetrazolium salt is chloride. INT which gets reduced from a colorless solution due to the presence of tetrazolium salt to a colored derivative called formazans. Due to the reduction potential of INT, it is widely used in redox histochemistry and various biological assays. The reduction occurs in the presence of NADPH or NADH (Sephra, 2012).

An experiment using 96-well plates was performed with INT dye and indicator resazurin side by side to compare the two indicators qualitatively based on their color change. All experimental components such as bacteria, media, plant extract, and resazurin in their appropriate concentrations

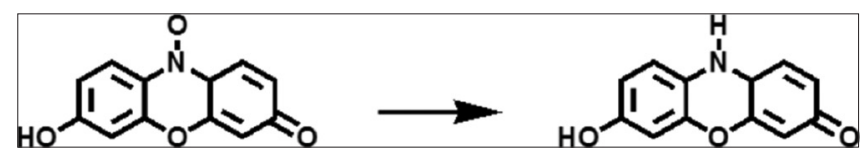

Figure 3: Reduction of resazurin to resorufin by the living cells. (The resazurin (blue) gets reduced to resorufin (pink) in the living systems) were added to the 96-well plate with resazurin while in the case of the plate with INT, all the above components were added except INT.Then, the 96 -well plate was sealed and incubated at $37^{\circ} \mathrm{C}$ for $24 \mathrm{~h}$. INT was added after $24 \mathrm{~h}$, and the well plate was kept in the incubator again at $37^{\circ} \mathrm{C}$ for $30 \mathrm{~min}$. The change in the color of dye INT from pale yellow (no bacterial growth) to pink (bacterial growth) and color change of resazurin from blue (no bacterial growth) to pink (bacterial growth) were noted. Resazurin in 96-well plate generated more accurate and clear results as compared to INT when observed with naked eye. Therefore, resazurin was further used as an indicator in all the experiments to determine MIC.

\section{MIC Determination using 96-Well Plate Assay}

Two separate 96-well plates were labeled, one for each Gram-negative and Gram-positive bacteria. The first row in each plate contained media control and gentamicin as a positive control. Initially, 30\% DMSO was tested and was found to be bactericidal. Therefore, different concentrations of DMSO were tested and 20\% DMSO was optimized as the safe limit for bacteria. Then, 20\% DMSO was added to as negative control, and the third row contained various concentrations of the reconstituted plant extract. $10 \mathrm{ul}$ of pre-diluted bacterial cells were added to each well where $10 \mathrm{ul}$ of $0.1 \%$ resazurin was used as an indicator. The plates were covered with the plate sealer and kept in the incubator at $37^{\circ} \mathrm{C}$ for $24 \mathrm{~h}$. Each experiment was carried out in triplicates, and the assay was repeated twice. Microbial growth was determined by observing the color change of the indicator resazurin in the wells (blue when there was no bacterial growth while pink when there was growth). MIC was recorded as the minimum concentration at which there was no color change in the wells.

\section{RESULTS}

Our GC-MS profiling found a high probability of acetic acid as an essential antibacterial compound present in A. magdalenae [Table 1 and Figure 4]. This evaluation was further confirmed by testing various concentrations of acetic acid $(1 \%, 2 \%$, and $5 \%)$ against bacteria E. coli. The zone of inhibition for $5 \%$ acetic acid was highest $(8.0 \mathrm{~mm})$, nearly same as gentamicin. With a concentration of $2 \%$ acetic acid, the zone of inhibition was $4.5 \mathrm{~mm}$, and a concentration of $1 \%$ acetic acid did not kill bacteria. These data confirmed the antibacterial activity of acetic acid [Figure 5].

Results of the comparative study showed that the color change of INT dye in 96-well plates demonstrated similar 
Table 1: The GC-MS profiling of rhizome of $A$. magdalenae

\begin{tabular}{|c|c|c|c|c|c|c|}
\hline RT & Compound & Formula & Probability & Chemical group & $\begin{array}{l}\text { Pharmacological } \\
\text { activity }\end{array}$ & Citation \\
\hline 8.362 & $\begin{array}{l}\text { 4-Hydroxymandelic acid, } \\
\text { ethyl ester, di-TMS }\end{array}$ & $\mathrm{C} 16 \mathrm{H} 2804 \mathrm{SI} 2$ & 17.2 & & & \\
\hline 10.929 & Heptanol & $\mathrm{C} 7 \mathrm{H} 140$ & 39.9 & Alcohol & & \\
\hline 11.662 & Furan. 2-pentyl & $\mathrm{C} 9 \mathrm{H} 140$ & 57 & & & \\
\hline 12.047 & 1-Pentanol & $\mathrm{C} 5 \mathrm{H} 12 \mathrm{O}$ & 16.9 & Alcohol & & \\
\hline 13.625 & 1-Hexanol & $\mathrm{C} 6 \mathrm{H} 140$ & 27.9 & Alcohol & & \\
\hline 14.978 & 2-Hexadecanol & $\mathrm{C} 16 \mathrm{H} 340$ & 11.9 & Alcohol & Antibacterial & $\begin{array}{l}\text { Kubo I, Muroi H, Kubo A. Naturally occurring } \\
\text { antiacne agents. J Nat Prod 1994;57:9-17 }\end{array}$ \\
\hline 15.172 & Acetic acid & $\mathrm{C} 2 \mathrm{H} 402$ & 90.9 & Carboxylic acid & Antibacterial & $\begin{array}{l}\text { Kubo I, Muroi H, Kubo A. Naturally occurring anti } \\
\text { acne agents. J Nat Prod 1994;57:9-17 }\end{array}$ \\
\hline 15.481 & Furfural & $\mathrm{C} 5 \mathrm{H} 402$ & 67.4 & $\begin{array}{l}\text { Heterocyclic } \\
\text { aldehyde }\end{array}$ & Antifungal & $\begin{array}{l}\text { Palmqvist } \mathrm{E} \text {, Almeida JS, Hahn-Hägerdal BZ. } \\
\text { Influence of furfural on anaerobic glycolytic kinetics } \\
\text { of Saccharomyces cerevisiae in batch culture. } \\
\text { Biotechnology Bioengineering 1999;62:447-54 }\end{array}$ \\
\hline 16.396 & Benzaldehyde & $\mathrm{C} 7 \mathrm{H} 60$ & 39.8 & Aldehyde & Antispasmodic & $\begin{array}{l}\text { Macht DI. A pharmacological examination of } \\
\text { benzaldehyde and mandelic acid. J Am Pharm Assoc } \\
\text { 1922;11:897-904 }\end{array}$ \\
\hline 16.665 & $\begin{array}{l}\text { Propanoic acid, } \\
\text { 2-methyl (isobutyric acid) }\end{array}$ & $\mathrm{C} 4 \mathrm{H} 802$ & 50.8 & Carboxylic acid & & \\
\hline
\end{tabular}

The table shows the retention time (RT) at which the acetic acid from the rhizome of plant A. magdalenae eluted from the column of GC-MS. Acetic acid shown to have a high probability (90.9\%). The pharmacological activity of acetic acid demonstrated its antibacterial properties, GC-MS: Gas chromatography-mass spectrometry, A. magdalenae: Aechmea magdalenae

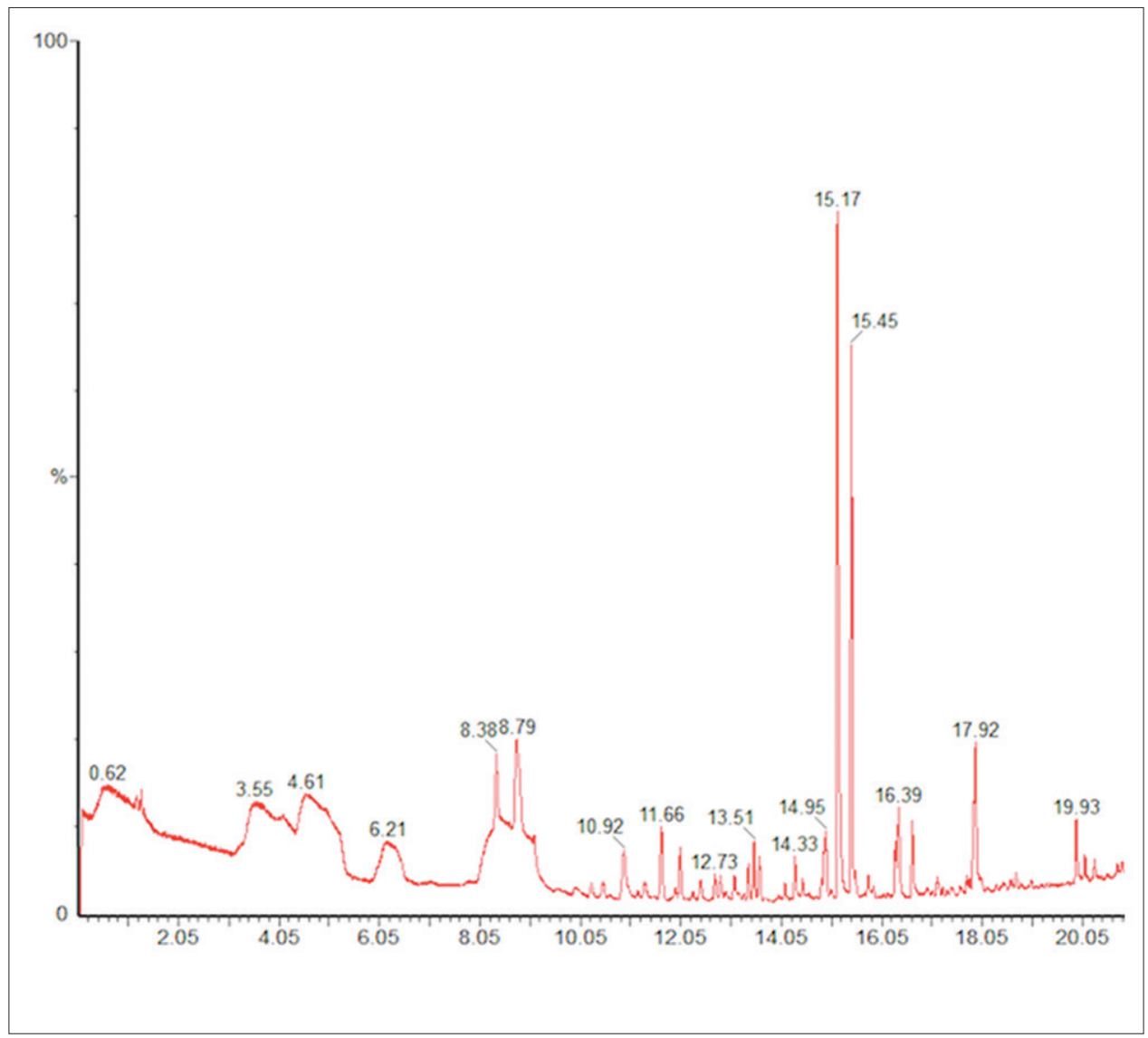

Figure 4: Gas chromatography-mass spectrometry spectra of Aechmea magdalenae rhizome. The above chromatogram shows the acetic acid peak of Aechmea magdalenae rhizome at the retention time 15.17 which corresponds in Table 1

trends as resazurin with the growth of bacteria. In both the dyes, color changed to pink when there was bacterial growth. The color of INT remained pale yellow while resazurin turned blue when there was no bacterial growth. The color change in INT was not as intense as it was in the wells with resazurin. In some wells with INT where there 


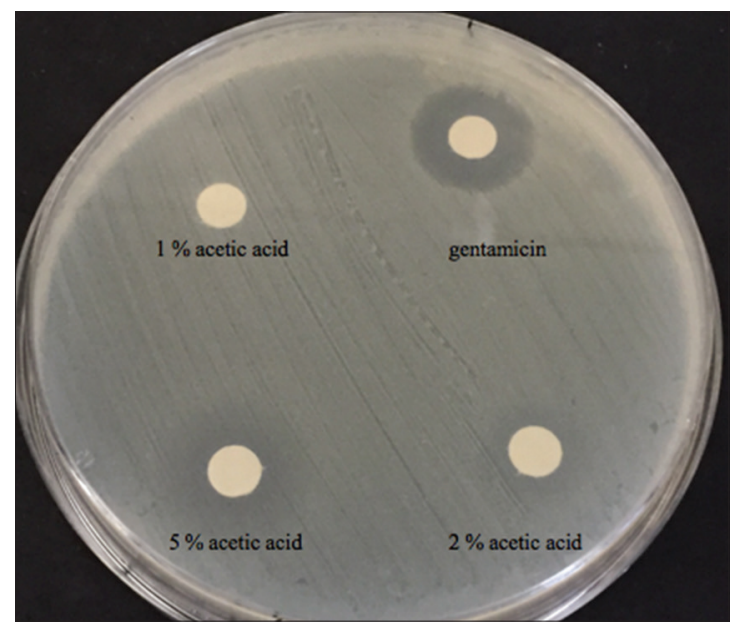

Figure 5: Zone of inhibition of Escherichia coli using various concentrations of acetic acid. The image shows the agar disc diffusion assay of the acetic acid from concentrations1-5\% against Escherichia coli and gentamicin as a positive control

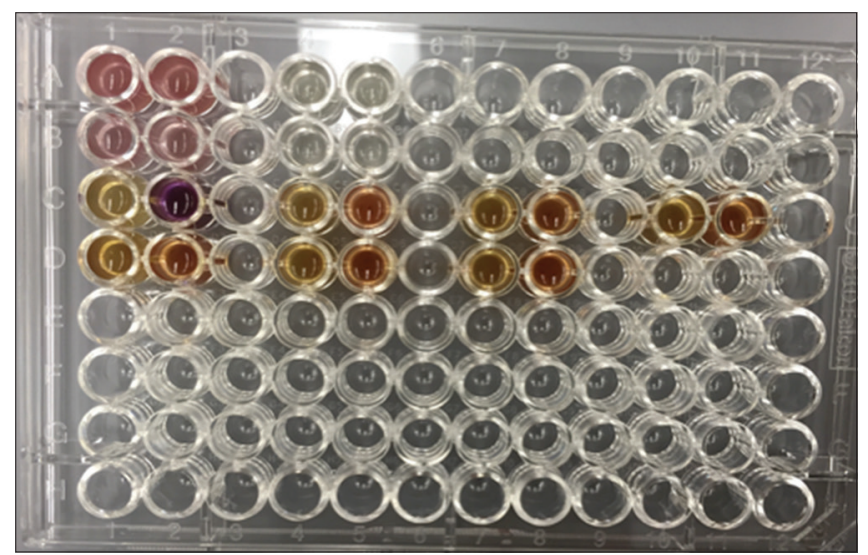

Figure 6: Comparison of indicator INT with resazurin in 96-well plate. The above 96-well plate shows the comparison of INT in wells $\mathrm{C} 1$, C4, C7, C10, D1, D4, and D7 with resazurin in wells C2, C5, C8, C11, D2, D5, and D8. In the wells with resazurin as an indicator, the color was distinct blue with no bacterial growth versus pink where there was bacterial growth with no intermediate color. In contrast, the wells with INT having intermediate colors with bacterial growth versus no growth

was no bacterial growth, the color was pale yellow while in the other no bacterial growth wells, the color was dark yellow. The color change was not intense enough to deduce the results. Similarly, in the wells with bacterial growth the color varied from light pink to dark pink, this variation in the pink color pertained to the amount of Formazan formed which was difficult to interpret by naked eye. In contrast, the wells having resazurin as an indicator were prominently either dark blue (no bacterial growth) or pink (bacteria growth) and no intermediate color variations [Figure 6]. Therefore, resazurin was considered as the better indicator for microbiological assays as compared to INT.

In this study, the extract of Bromeliad A. magdalenae was prepared in methanol, as methanol is considered to be

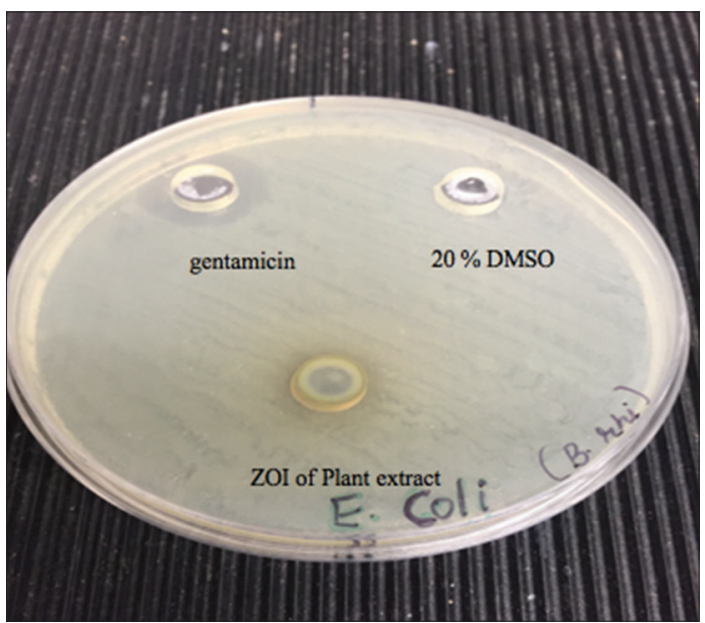

Figure 7: Zone of inhibition in Escherichia coli. The image displays the agar well diffusion assay having gentamicin as a positive control, $20 \%$ dimethyl sulfoxide as a negative control and the zone of inhibition of methanolic extract of Aechmea magdalenae against Escherichia coli

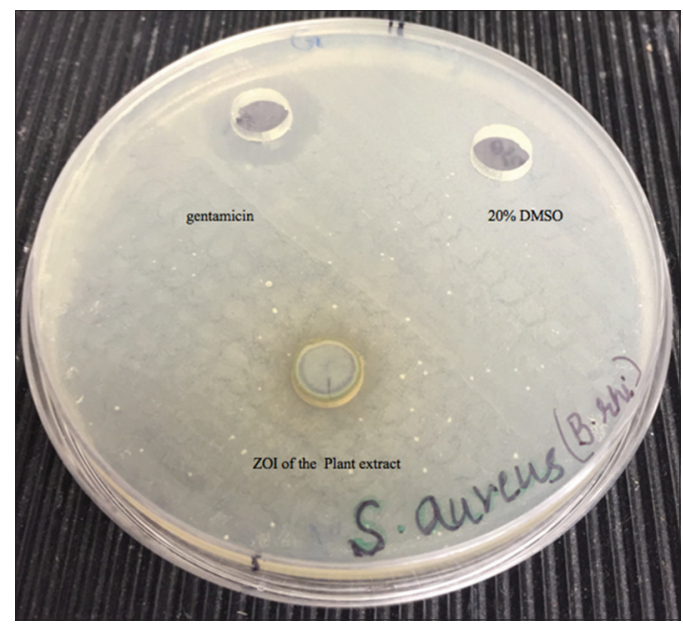

Figure 8: Zone of inhibition in Staphylococcus aureus. The image displays the agar well diffusion assay having gentamicin as a positive control, $20 \%$ dimethyl sulfoxide as a negative control and the zone of inhibition of methanolic extract of Aechmea magdalenae against Staphylococcus aureus

one of the most effective solvents to extract out chemical compounds necessary for antibacterial activity (Tekwu et al., 2012; Robles-Zepeda et al., 2013). Methanolic extracts of $A$. magdalenae's rhizome showed very pronounced inhibitory effects in agar well diffusion assays, against the Gram-negative and Gram-positive bacteria tested [Table 2]. The zone of inhibition in E. coli [Figure 7] was consistently smaller than that of S. aureus [Figure 8]. These results indicated that the $A$. magdalenae extract was more potent against S. aureus than E. coli.

In the 96-well plate assay, the methanolic extract of A. magdalenae rhizome inhibited the growth of both the E. coli and S. aureus. The MIC analysis for the 96-well plate assay found that the concentration of plant extract required 
Table 2: Antibacterial activity of the methanolic extract of rhizome of $A$. magdalenae using agar well diffusion assay

\begin{tabular}{lcccc}
\hline Microbes tested & ZOI $(\mathrm{mm})$ of the methanolic rhizome PE & $\begin{array}{c}\text { ZOI }(\mathrm{mm}) \text { of } 1 \mathrm{mg} / \mathrm{ml} \\
\text { chlorhexidine }\end{array}$ & $\begin{array}{c}\text { ZOI }(\mathrm{mm}) \text { of I mg/ml } \\
\text { gentamicin }\end{array}$ & Z0I (mm) of 20\% DMSO \\
\hline E. coli & 9.5 & 13.5 & 14.0 & 0.0 \\
S. aureus & 10.5 & 14.0 & 15.0 & 0.0 \\
\hline
\end{tabular}

ZOI: Zone of inhibition, PE: Plant extract, DMSO: Dimethyl sulfoxide, MIC: Minimum inhibitory concentration. The table demonstrates the zones of inhibition by methanolic plant extract, chlorhexidine and gentamicin (positive controls) and 20\% DMSO (negative control), A. magdalenae: Aechmea magdalenae

to inhibit the growth of E. coli was higher than that needed to inhibit S. aureus [Table 3]. In all the assays, the positive controls of gentamicin and chlorhexidine consistently killed the bacteria (resazurin remained blue), but 20\% DMSO (negative control) did not cause mortality. These results support the observation from agar well diffusion assays that S. aureus was more sensitive to the plant extract than E.coli.

\section{DISCUSSION}

In the agar disc diffusion assay, concentrations of acetic acid between $1 \%$ and $5 \%$ demonstrated excellent bactericidal effects. Similar effects for acetic acid were found in the study conducted by Ryssela et al. (2009) and Sloss et al. (1993). These studies suggested that the bactericidal concentration of acetic acid was between $1 \%$ and $5 \%$ and was particularly effective against Gram-negative (E.coli and P. aeruginosa) as well as Gram-positive bacteria (S. aureus). Importantly, there are several chemical compounds other than acetic acid such as flavonoids that may be responsible for antibacterial and antifungal properties of Bromeliads (Camacho-Hernández et al., 2002).

In 2016, a study was conducted by Obey et al., on stem bark of a Kenyan plant, Croton macrostachyus to be used as antimicrobial agent. In Kenya, the leaves and roots of the plant C. macrostachyus are traditionally used as medicine against infectious diseases such as typhoid and measles but no study was done using stem bark other than the above study. In this study, a methanolic extract of stem bark was tested against important Gram-negative bacteria using agar well diffusion assay. The zones of inhibition of agar well diffusion assay obtained with $E$. coli $(9.0 \mathrm{~mm})$ were very close to the zones of inhibition of the present study using E. coli $(9.5 \mathrm{~mm})$.

According to an antibacterial study conducted on the leaves and stem of plant Persea americana (avocado) by Ogundare and Oladejo, the zones of inhibition obtained by methanolic bark extract using agar well diffusion assay using gram positive bacteria (S. aureus) was $12.0 \mathrm{~mm}$. These results are close to the present study which shows the zones of inhibition of $10.5 \mathrm{~mm}$ against S. aureus (Table 2). Also, the MIC attained using 96 well plate assay for $S$. aureus in the above discussed study (Ogundare and Oladejo, 2014) was
Table 3: MIC of the $A$. magdalenae rhizome extract using 96-well plate assay

\begin{tabular}{lc}
\hline Microbes tested & MIC $(\mathrm{mg} / \mathrm{ml})$ of rhizome extract \\
\hline E. coli & 190.06 \\
S. aureus & 11.30 \\
\hline
\end{tabular}

The table depicts the MIC of the Gram-negative; E. coli and

Gram-positive bacteria; S. aureus. A. magdalenae: Aechmea magdalenae, E. coli: Escherichia coli, S. aureus: Staphylococcus aureus, MIC: Minimum inhibitory concentration

$10.0 \mathrm{mg} / \mathrm{mL}$, which is in well accordance with the MIC obtained for S. aureus $(11.30 \mathrm{mg} / \mathrm{mL})$ in the present study.

The MIC obtained from 96-well plate assays was higher for E. coli than S. aureus [Table 3], indicating that the plant extracts were less potent against Gram-negative bacteria than Gram-positive bacteria. These results are in accordance with another study conducted by $\mathrm{Vu}$ et al. (2015). In their research, the scientists collected several Vietnamese medicinal plants to study the antibacterial activity against human pathogenic bacteria. According to this study, the Vietnamese medicinal plant extracts were less active against Gram-negative bacteria compared to Gram-positive bacteria. The possible reason for this differential effectiveness might pertain to the impenetrable cell wall structure with peptidoglycan layer which makes Gram-negative bacteria more resistant to antibiotics(Melanovic and Lohner, 2016).

Interestingly, no study has been reported the antibacterial activity of the rhizomes or leaves of the bromeliad A. magdalenae. Previous studies conducted mainly focused on the antibacterial activities of fruits and leaves of other members of family Bromeliaceae (Raimundo et al., 2014). Since some indigenous cultures throughout its range use A. magdalenae as a caustic for wounds (Ticktin, 2002), we find it important to document its efficacy and antimicrobial potential using western science. The GC-MS profiling showed low probability (27.7\%) of acetic acid in leaves of $A$. magdalenae, therefore, we have chosen the rhizome as our starting material with a high probability $(90.9 \%)$ of acetic acid. Hence, the present study scientifically supports the view of methanolic extracts of $A$. magdalenae rhizomes having antibacterial properties. 


\section{CONCLUSION}

Increasingly, disease-causing agents are evolving resistance to present day antibiotics. To overcome this problem, recently a large number of herbal plants have been studied and widely used as antimicrobials. In this study, rhizomes of plant $A$. magdalenae have clearly elucidated the presence of antibacterial activity against E. coli and S. aureus, with a little more antibacterial potential against the Grampositive than Gram-negative bacteria. This study provides preliminary evidence to support the use of extracts from plant $A$. magdalenae as a novel antibacterial medicine. In particular, our findings in terms of its affects on S. aureus, a cause of numerous skin diseases worldwide, support its use by traditional cultures in the treatment of wound infections.

\section{ACKNOWLEDGMENT}

Authors are thankful to Kean University, for providing the platform to conduct this research. Authors also wish to express their thanks to Ms. Yuriko Root, from Organic Chemistry Lab, Kean University, for her constant help during this project. We are grateful to the peers Mirna Giron and Quintin Ferraris, for their help and support in this project.

\section{REFERENCES}

Balick MJ, Cox PA. Plants, people and culture: The science of ethno botany. J Nat Prod 1997;60:428-9.

Bauer AW, Kirby WM, Sherris JC, Turck M. Antibiotic susceptibility testing by a standardized single disk method. Am J Clin Pathol 1966;45:493-6.

Camacho-Hernández IL, Chávez-Velázquez JA, Uribe-Beltrán MJ, Ríos-Morgan A, Delgado-Vargas F. Antifungal activity of fruit pulp extract from Bromelia pinguin. Fitoterapia 2002;73:411-3.

Givnish TJ, Barfuss MH, Van Ee B, Riina R, Schulte K, Horres R, et al. Phylogeny, adaptive radiation, and historical biogeography in Bromeliaceae: Insights from an eight-locus plastid phylogeny. Am. J. Bot 2011;98:827-95.

Hazlett DL. Ethnobotanical observations from Cabecar and Guaymi settlements in central America. Econ Bot 1986;40:339-52.

Joung H, Lee J, Noh JK. Costa Rican Medicinal Plants I. Based on local knowledge in the Central Valley. Turrialba, Costa Rica:Tropical Agricultural Research and Higher Education Center (CATIE); 2008. p. 116.

Lincoln KM. The use and Potential of the Pita Plant, Aechmea magdalenae (andré) André ex. Baker, in Angöbe Village: A Case Study of Chalite, Bocas delToro, Panama. A Master's Thesis. Michigan Technological University; 2004.

Luther HE. An alphabetical list of bromeliad binomials. Sarasota.
The Bromeliad Society International. $11^{\text {th }}$ ed. Florida, USA: Bromeliad Society International; 2008.

Malanovic N, Lohner K. Gram-positive bacterial cell envelopes: The impact on the activity of antimicrobial peptides. Biochem Biophys Acta 2016;1858:936-46.

Manetti LM, Delaporte RH, Laverde-Júnior A. Metabólitossecundários da familia Bromeliaceae. Quim Nova 2009;32:1885-97.

Obey JK, von Wright A, Orjala J, Kauhanen J, TikkanenKaukanen C. Antimicrobial activity of Croton macrostachyus stem bark extracts against several human pathogenic bacteria. J Pathog 2016;2016:1453428.

Ogundare AO, Oladejo BO. Antibacterial activities of the leaf and bark extract of Persea Americana. Am J Ethnomed 2014;1:64-71.

Payrol JA, Martinez MM. Estudiofarmacognóstico de Bromelia pinguin L. (Piña de Ratón). Rev Cubana Farm 2000;34:181-6.

Pío-León JF, López-Angulo G, Paredes-López O, UribeBeltrán Mde J, Díaz-Camacho SP, Delgado-Vargas F, et al. Physicochemical, nutritional and antibacterial characteristics of the fruit of Bromelia pinguin L. Plant Foods Hum Nutr 2009;64:181-7.

Raffauf RF, Menachery MD, Quesne PW, Arnold EV, Clardy J. Diterpenoid and flavonoid constituents of Bromeliapinguin L. J Org Chem 1981;46:1094-8.

Rampersad SN. Multiple applications of alamar blue as an Indicator of metabolic function and cellular health in cell viability bioassays. Sensors (Basel) 2012;12:12347-60.

Recio MC, Rios JL. A review of some antimicrobial compounds isolated from medicinal plants reported in the literature 1978-1988. Phytoter Res 1989;3:117-25.

Robles-Zepeda RE, Coronado-Aceves EW, VelazquezContreras CA, Ruiz-Bustos E, Navarro-Navarro M, Garibay-Escobar A. In vitro anti-mycobacterial activity of nine medicinal plants used by ethnic groups in Sonora, Mexico. BMC Complement Altern Med 2013;13:329.

Ryssela H, Kloetersa O, Germanna G, Schäfera TH, Wiedemanna G, Oehlbauer M. The antimicrobial effect of acetic acid. An alternative to common local antiseptics. Burns 2009;35:695-700.

Santana CR, Oliveira-Junior RG, Araújo CS, Souza GR, LimaSaraiva SR, Guimarães AL, et al. Phytochemical screening, antioxidant and antibacterial activity of Encholirium spectabile (Bromeliaceae). Int J Sci 2012;1:1-19.

Shebitz DJ, Eaton W. Forest structure, nutrients and Pentaclethra macroloba. Growth after deforestation of Costa Rican lowland forests. ISRN Ecol 2013;2013:414357.

Silver LL, Bostian KA. Discovery and development of new antibiotics: The problem of antibiotic resistance. Antimicrob Agents Chemother 1993;37:377-83.

Sloss JM, Cumberland N, Milner SM. Acetic acid used for the elimination of Pseudomonasaeruginosa from burn and soft 
tissue wounds. J R Army Med Corps 1993;139:49-51.

Taye B, Giday M, Animut A, Seid J. Antibacterial activities of selected medicinal plants in traditional treatment of human wounds in Ethiopia. Asian Pac JTrop Biomed 2011;5:370-5.

Tekwu EM, Pieme AC, Beng VP. Investigations of antimicrobial activity of some Cameroonian medicinal plant extracts against bacteria and yeast with gastrointestinal relevance. J Ethnopharmacol 2012;142:265-73.

Ticktin T. The history of Ixtle in Mexico. Econ Bot 2002;56:920-94.
Villegas AC. Spatial and temporal variability in clonal reproduction of Aechmea magdalenae, a tropical understory Herb. Biotropica 2001;33:48-59.

VuTT, Kim H, Tran VK, Le Dang Q, Nguyen HT, Kim H, et al. In vitro antibacterial activity of selected medicinal plants traditionally used in Vietnam against human pathogenic bacteria. BMC Complement Altern Med 2016;16:32.

Webster D, Taschereau P, Belland RJ, Sand C, Rennie RP. Antifungal activity of medicinal plants extract; Preliminary screening studies. J. Ethnopharm 2008;115:140-6. 